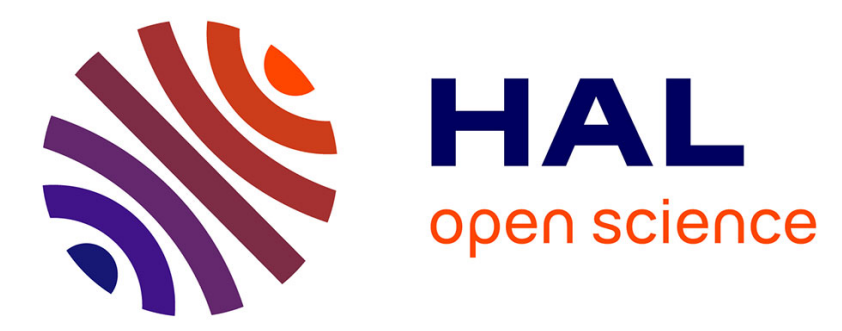

\title{
Correlative responses for carcass and meat quality traits to selection for ovulation rate or prenatal survival in French Large White pigs
}

Adalberto Rosendo-Ponce, Tom Druet, Christophe Péry, Jean Pierre Bidanel

\section{To cite this version:}

Adalberto Rosendo-Ponce, Tom Druet, Christophe Péry, Jean Pierre Bidanel. Correlative responses for carcass and meat quality traits to selection for ovulation rate or prenatal survival in French Large White pigs. Journal of Animal Science, 2010, 88 (3), pp.903-911. 10.2527/jas.2009-2326 . hal01193515

\section{HAL Id: hal-01193515 \\ https://hal.science/hal-01193515}

Submitted on 31 May 2020

HAL is a multi-disciplinary open access archive for the deposit and dissemination of scientific research documents, whether they are published or not. The documents may come from teaching and research institutions in France or abroad, or from public or private research centers.
L'archive ouverte pluridisciplinaire HAL, est destinée au dépôt et à la diffusion de documents scientifiques de niveau recherche, publiés ou non, émanant des établissements d'enseignement et de recherche français ou étrangers, des laboratoires publics ou privés. 


\section{JOURNAL OF ANIMAL SCIENCE}

The Premier Journal and Leading Source of New Knowledge and Perspective in Animal Science

Correlative responses for carcass and meat quality traits to selection for ovulation rate or prenatal survival in French Large White pigs 1

A. Rosendo, T. Druet, C. Péry and J. P. Bidanel

J ANIM SCI 2010, 88:903-911.

doi: 10.2527/jas.2009-2326 originally published online December 4, 2009

The online version of this article, along with updated information and services, is located on the World Wide Web at:

http://www.journalofanimalscience.org/content/88/3/903 


\title{
Correlative responses for carcass and meat quality traits to selection for ovulation rate or prenatal survival in French Large White pigs $^{1}$
}

\author{
A. Rosendo ${ }^{*} \dagger^{2}$ T. Druet, ${ }^{*} \dagger$ C. Péry $\$$ and J. P. Bidanel $* \dagger^{3}$ \\ *INRA, UMR1313 Génétique Animale et Biologie Intégrative, F-78350 Jouy-en-Josas, France; \\ $\dagger$ † AroParisTech, UMR1313 Génétique Animale et Biologie Intégrative, F-75231 Paris, France; \\ and $\ddagger$ INRA, UE332 Domaine de Galle, F-18520 Avord, France
}

\begin{abstract}
Correlated effects of selection for components of litter size on carcass and meat quality traits were estimated using data from 3 lines of pigs derived from the same Large White base population. Two lines were selected for 6 generations on high ovulation rate at puberty (OR) or high prenatal survival corrected for ovulation rate in the first 2 parities (PS). The third line was an unselected control (CON). The 3 lines were kept for a 7th generation, but without any selection. Carcass and meat quality traits were recorded on the 5 th to 7 th generation of the experiment. Carcass traits included dressing percentage, carcass length (LGTH), average backfat thickness (ABT), estimated lean meat content, and 8 carcass joint weight traits. Meat quality traits included $\mathrm{pH}$ recorded $24 \mathrm{~h}$ after slaughter $(\mathrm{pH} 24)$ of LM, gluteus superficialis (GS), biceps femoris (BF), and adductor femoris (AD) muscles, as well as reflectance and water-holding capacity (WHC) of GS and BF muscles. Heritabilities of carcass and meat quality traits and their genetic correlations with OR and PS were estimated using REML methodology applied to
\end{abstract}

a multiple trait animal model. Correlated responses to selection were then estimated by computing differences between OR or PS and CON lines at generations 5 to 7 using least squares and mixed model methodology. Heritability $\left(\mathrm{h}^{2}\right)$ estimates were $0.08 \pm 0.04,0.58 \pm$ $0.10,0.70 \pm 0.10$, and $0.74 \pm 0.10$ for dressing percentage, LGTH, ABT, and lean meat content, respectively, ranged from 0.28 to 0.72 for carcass joint traits, from 0.28 to 0.45 for $\mathrm{pH} 24$ and reflectance measurements, and from 0.03 to 0.11 for WHC measurements. Both OR and PS had weak genetic correlations with carcass $\left(\mathrm{r}_{\mathrm{G}}=-0.09\right.$ to 0.17$)$ and most meat quality traits. Selection for OR did not affect any carcass composition or meat quality trait. Correlated responses to selection for PS were also limited, with the exception of a decrease in pH24 of GS and BF muscles ( -0.12 to -0.14 after 6 generations; $P<0.05)$, in WHC of GS muscle $(-18.9$ s after 6 generations; $P<0.05)$ and a tendency toward an increase in loin weight $(0.44 \mathrm{~kg}$ after 6 generations; $P<0.10)$.

Key words: carcass composition, meat quality, ovulation rate, pig, prenatal survival, selection experiment

(C) 2010 American Society of Animal Science. All rights reserved.

J. Anim. Sci. 2010. 88:903-911 doi:10.2527/jas.2009-2326

\section{INTRODUCTION}

Litter size is a major component of the breeding goal in pig dam lines (Estany et al., 2002; Holl and Robinson, 2003; Hamann et al., 2004). There is experimental evidence that prolificacy has been substantially

\footnotetext{
${ }^{1}$ The thesis work of A. Rosendo is funded by the Consejo Nacional de Ciencia y Tecnologia, the Secretaria de Educacion Publica, Programa de Becas Complemantarias, México, and Colegio de Postgraduados, Mexico.

${ }^{2}$ Present address: Colegio de Postgraduados, Campus Veracruz km 26.5 carr. Fed. Veracruz-Xalapa, Predio Tepetates, Mpio. De Manlio Fabio Altamirano CP 91700, Apdo. Postal 421, Veracruz, Mexico.

${ }^{3}$ Corresponding author: jean-pierre.bidanel@jouy.inra.fr

Received July 21, 2009.

Accepted October 26, 2009.
}

improved by applying high selection intensities in pig maternal lines (Bidanel et al., 1994a; Tribout et al., 2003). However, direct selection for litter size remains difficult in closed maternal lines where extreme selection intensities cannot be applied. Selecting on ovulation rate and prenatal survival has been proposed as an alternative to direct selection to improve litter size at birth (Johnson et al., 1984). A selection experiment on ovulation rate or prenatal survival was set up at the Institut National de la Recherche Agronomique (INRA) to estimate their genetic parameters and check their potential as selection criteria for litter size (Blasco et al., 1998; Rosendo et al., 2007b). Before commercial application, direct and correlated responses to selection for the main traits of interest in pig production should be estimated. Correlated responses for reproductive and growth traits were presented in Rosendo et 
Table 1. Average reproductive performance of the $3 \operatorname{lines}^{1}$ (and their SE) on the 5th, 6th, and 7th generations (from Rosendo et al., 2007a,b)

\begin{tabular}{|c|c|c|c|}
\hline Item & Control line & OR line & PS line \\
\hline \multicolumn{4}{|l|}{ 5th generation } \\
\hline Ovulation rate & $16.1(0.3)$ & $19.0(0.3)$ & $16.4(0.3)$ \\
\hline Prenatal survival & $60.2(2.4)$ & $52.1(2.4)$ & $61.2(2.4)$ \\
\hline Litter size & $9.7(0.3)$ & $9.9(0.4)$ & $9.8(0.4)$ \\
\hline Birth weight, $\mathrm{kg}$ & $1.32(0.04)$ & $1.33(0.04)$ & $1.34(0.04)$ \\
\hline \multicolumn{4}{|l|}{ 6th generation } \\
\hline Ovulation rate & $16.2(0.3)$ & $19.2(0.3)$ & $16.1(0.3)$ \\
\hline Prenatal survival & $59.9(2.4)$ & $55.2(2.4)$ & $68.3(2.4)$ \\
\hline Litter size & $9.7(0.4)$ & $10.6(0.4)$ & $11.0(0.4)$ \\
\hline Birth weight, kg & $1.35(0.04)$ & $1.28(0.04)$ & $1.24(0.04)$ \\
\hline \multicolumn{4}{|l|}{ 7th generation } \\
\hline Ovulation rate & $16.9(0.4)$ & $18.9(0.5)$ & $16.6(0.4)$ \\
\hline Prenatal survival & $53.5(3.1)$ & $51.8(3.3)$ & $64.4(3.1)$ \\
\hline Litter size & $10.2(0.5)$ & $9.9(0.5)$ & $10.7(0.5)$ \\
\hline Birth weight, $\mathrm{kg}$ & $1.31(0.05)$ & $1.34(0.05)$ & $1.29(0.05)$ \\
\hline
\end{tabular}

al. $(2007 \mathrm{a}, \mathrm{c})$. The objective of the present study is to analyze correlated responses to selection for ovulation rate or prenatal survival on various carcass and meat quality traits.

\section{MATERIALS AND METHODS}

Animal care followed the general guidelines outlined in the European welfare regulation (directive 91/630/ EC).

\section{Animals and Experimental Design}

The experiment was carried out over 7 generations (6 generations of selection and a seventh generation of random mating) at the INRA experimental herd of Galle (Avord, France).

Two lines of pigs were selected for high ovulation rate at puberty (OR) or high prenatal survival (PS) over the first 2 parities corrected for ovulation rate at fertilization (ORF). Prenatal survival was computed as (total number born/ORF) $+(0.018 \times$ ORF) (Rosendo et al., 2007b). The correction term was introduced to avoid trends in PS associated with variation in OR. The term 0.018 represented an average literature value for the phenotypic regression coefficient of PS on ORF. A third line was kept as an unselected control (CON line). At each generation, approximately 50 gilts and 6 to 8 boars from first litters were kept for breeding. Boars were chosen on a within-sire family basis in the 3 lines, whereas sows were selected on a population basis in the 2 selected lines and within-dam families in the CON line (Rosendo et al., 2007b). A mating plan was established that minimized inbreeding at each generation. Additional details on the experimental design are given by Rosendo et al. (2007b). Average reproductive performance of the 3 lines on the 5th, 6th, and 7th generations are given in Table 1.
The sow herd was managed under a batch farrowing system. Females were distributed into 7 farrowing batches, which then became postweaning and performance test batches of their progeny. Seven gilts from each line were introduced in each farrowing batch. Females produced 2 experimental litters. Replacement animals were chosen in first parity litters, whereas pigs from second parity litters were all slaughtered. All piglets were weaned at $4 \mathrm{wk}$ of age and moved to a postweaning unit until $10 \mathrm{wk}$ of age. They were then allotted to a performance test building in which they were housed in pens of 10 to 12 animals of the same line, where they stayed until the end of the test period when the average BW within a pen reached $90 \mathrm{~kg}$. Animals were fed ad libitum with a single pelleted diet based on cereals and soybean meal containing $3,100 \mathrm{kcal}$ of $\mathrm{DE} / \mathrm{kg}$ and 170 $\mathrm{g}$ of $\mathrm{CP} / \mathrm{kg}$ during the whole test period and until the day before slaughter. Additional details on the performance test can be found in Rosendo et al. (2007a).

Carcass and meat quality traits were measured only on second litters from the 5th, 6th, and 7th generation of the experiment. On average, 2 pigs per litter (i.e., 1 gilt and 1 castrate) were chosen at random within each litter and were slaughtered in a commercial abattoir at an average BW of $100.6 \pm 2.6 \mathrm{~kg}$. All animals were fasted for $16 \mathrm{~h}$ before they were transported for $2 \mathrm{~h}$ to the abattoir where they were allowed to rest for an additional $18 \mathrm{~h}$ before they were killed by electrical stunning and immediate exsanguination.

\section{Measurements}

Carcass measurements were recorded on the day after slaughter. Dressing percentage (DP) was calculated as the ratio of cold carcass (with head and feet) to unfasted BW. Carcass length (LGTH), measured from the cervical vertebra to the anterior edge of the pubic symphysis, and average backfat thickness (ABT), mea- 
sured at the levels of first rib, last rib, and last lumbar vertebrae, were recorded on the right half-carcass. The kidney and leaf fat were removed, and the right halfcarcass was divided into 7 cuts. The front and back feet were separated from the limbs at the levels of the carpal bones and tibio-tarsal joint, respectively. The ham was isolated along a first line parallel to the general direction of the sacrum and a second line perpendicular to the long axis of the carcass between the last lumbar and the first sacral vertebrae. The loin was separated from the belly and the shoulder with a cut starting under the psoas muscle at the level of the last lumbar vertebra and ending under the blade bone. The belly and the shoulder were separated with a cut perpendicular to the long axis of the carcass between the 5th and the 6th rib. The backfat was dissected from the loin, but the other cuts remained untrimmed. The weight of 8 cuts [i.e., backfat (BFWT), belly (BEWT), feet (FWT), ham (HAWT), head (HEWT), leaf fat (LFWT), loin (LOWT), and shoulder (SWT)] were recorded, and carcass lean meat content (LMC) was estimated from the 3 joint weights using the following equation (Larzul et al., 1999b); LMC $=16.56+(71.6$ HAWT +83.0 LOWT - 76.2 BFWT)/half-carcass weight.

Meat quality traits were also measured $24 \mathrm{~h}$ postmortem. Ultimate $\mathrm{pH}$ (pH24) was taken directly on different types of muscles [i.e., on LM, gluteus superficialis (GS), biceps femoris (BF), and adductor femoris (AD)] muscles using a combined glass electrode (Ingold, Metter Toledo, Switzerland) and a portable $\mathrm{pH}$ meter (CG818, Schott Geräte, Mainz, Germany). A Minolta Chromameter CR-300 (Minolta Camera Co. Ltd., Osaka, Japan) with a 8-mm aperture, a pulsed xenon arc lamp, CIE illuminant, and calibration to the white calibration plate, was used to measure lightness $\left(\mathbf{L}^{*}\right)$, redness/greenness $\left(\mathbf{a}^{*}\right)$, and yellowness/blueness $\left(\mathbf{b}^{*}\right)$ on BF and GS muscles. Water-holding capacity was measured on GS and BF muscles by the filter paper imbibition time method (Charpentier et al., 1971). This method consists of measuring the time required for the complete wetting of a piece of filter paper (around 1 $\mathrm{cm}^{2}$ ) put on the freshly cut surface of the muscle. The time of the observation is limited to $3 \mathrm{~min}$. Measurements on ham muscles (i.e., GS, BF, and AD muscles) were performed on the cut surface of the ham at the intersection of the ham and loin joints. Measurements on LM muscle were carried out at the level of the last rib. The number of records for each line $\times$ generation subclass ranged from 40 to 59 .

\section{Statistical Analyses}

A total of 12 carcass traits were analyzed (i.e., DP, LGTH, ABT, LMC, and the BFWT, HAWT, LOWT, SWT, FWT, LFWT, BEWT, and HEWT). Twelve meat quality traits were considered (i.e., the $4 \mathrm{pH} 24$ measurements, denoted by pH24_LM, pH24_GS, pH24_BF, and pH24_AD), 6 color measurements [i.e., $\mathrm{a}^{*} \mathrm{GS}$ and $\mathrm{a}{ }^{*} \mathrm{BF}$ (redness/greenness), $\mathrm{b}{ }^{*} \mathrm{GS}$ and $\mathrm{b}{ }^{*} \mathrm{BF}$ (yellowness/blueness), and $\mathrm{L}^{*} \mathrm{GS}$ and $\mathrm{L}^{*} \mathrm{BF}$ (lightness)], and 2 water-holding capacity measures denoted by WHC_GS and WHC_BF. Elementary statistics for the traits studied are given in Table 2.

Least Squares Analyses of Line Differences. The data were first analyzed using least squares methodology with the GLM procedure (SAS Inst. Inc., Cary, $\mathrm{NC}$ ). Least squares means for each line-generation subclass were computed using a linear model. Fixed effects for all traits included line (OR, PS, or CON), generation number $(5,6$, or 7$)$, their interaction, sex (female or castrate), and contemporary group. Contemporary group was defined by the fattening batch for carcass traits and slaughter date for meat quality traits. Parity of dam was included as a fixed effect in the model for carcass traits, and BW at slaughter and animal inbreeding coefficient were included in all models as linear covariates.

Mixed Model Analyses. Variance components were first estimated using REML methodology (Patterson and Thompson, 1971) applied to 3 trait mixed linear animal models including the selection criterion (OR and PS) and an additional trait. The models used depended on the trait (Table 3), but all derived from the following base model:

$$
\mathbf{y}=\mathbf{X} \boldsymbol{\beta}+\mathbf{Z}_{\mathrm{a}} \mathbf{a}+\mathbf{W}_{\mathrm{c}} \mathbf{c}+\mathbf{e},
$$

where $\mathbf{y}$ represents the vector of observations; $\mathbf{X}, \mathbf{Z}_{\mathrm{a}}$, and $\mathbf{W}_{\mathrm{c}}$ are known incidence matrices relating observations to fixed and random effects; $\boldsymbol{\beta}=$ vector of fixed effects (i.e., generation, line, sex, parity number of the dam, and contemporary group); $\mathbf{a}$ is the vector of direct genetics effects of the pig; $\mathbf{c}$ is a vector of random common litter effects of the animals; and $\mathbf{e}$ is the vector of random residual effects. The models used to estimate the variance components for OR and SP are detailed in Rosendo et al. (2007b). The following means and (co) variance structures were assumed across random effects in the model:

$$
\begin{gathered}
\mathrm{E}(\mathbf{y})=\mathbf{X} \boldsymbol{\beta} \\
\operatorname{var}\left[\begin{array}{l}
\mathbf{a} \\
\mathbf{c} \\
\mathbf{e}
\end{array}\right]=\left[\begin{array}{ccc}
\mathbf{A} \boldsymbol{\sigma}_{\mathrm{a}}^{2} & \mathbf{0} & \mathbf{0} \\
\mathbf{0} & \mathbf{I} \boldsymbol{\sigma}_{\mathrm{c}}^{2} & \mathbf{0} \\
\mathbf{0} & \mathbf{0} & \mathbf{I} \boldsymbol{\sigma}_{\mathrm{e}}^{2}
\end{array}\right],
\end{gathered}
$$

where $\sigma_{\mathrm{a}}^{2}$ is the additive genetic variance; $\mathbf{A}$ is the additive relationship matrix; $\sigma_{\mathrm{c}}^{2}$ and $\sigma_{\mathrm{e}}^{2}$ are the random common litter and residual variances, respectively; and I are the identity matrices of appropriate dimension. The analyses were performed using VCE (Neumaier and Groeneveld, 1998) and ASREML (Gilmour et al., 2002) computer packages. Additive genetic effects were then estimated as back-solutions from REML analyses 
Table 2. Descriptive statistics for carcass and meat quality traits

\begin{tabular}{|c|c|c|c|c|}
\hline Carcass trait & Abbreviation & $\mathrm{n}^{1}$ & Mean & $\mathrm{SD}$ \\
\hline Dressing percentage, $\%$ & $\mathrm{DP}$ & 584 & 76.6 & 2.5 \\
\hline Carcass length, mm & LGTH & 593 & 956 & 28 \\
\hline Average backfat thickness, mm & $\mathrm{ABT}$ & 593 & 28.1 & 4.6 \\
\hline \multicolumn{5}{|l|}{ Weight of joint, $\mathrm{kg}$} \\
\hline Backfat & BFWT & 593 & 4.02 & 0.75 \\
\hline Ham & HAWT & 593 & 8.83 & 0.57 \\
\hline Loin & LOWT & 593 & 10.99 & 0.85 \\
\hline Shoulder & SWT & 593 & 4.99 & 0.37 \\
\hline Feet & FWT & 593 & 1.08 & 0.1 \\
\hline Leaf fat & LFWT & 471 & 0.54 & 0.17 \\
\hline Belly & BEWT & 593 & 4.64 & 0.53 \\
\hline Head & HEWT & 588 & 6.76 & 0.58 \\
\hline Estimated lean meat content, $\%$ & LMC & 588 & 51.6 & 3.3 \\
\hline \multicolumn{5}{|l|}{ Meat quality trait ${ }^{2}$} \\
\hline pH24 of LM & pH24_LM & 480 & 5.58 & 0.23 \\
\hline pH24 of gluteus superficialis muscle & pH24_GS & 480 & 5.90 & 0.29 \\
\hline pH24 of biceps femoris muscle & pH24_BF & 480 & 5.59 & 0.23 \\
\hline pH24 of adductor femoris muscle & pH24_AF & 480 & 5.69 & 0.26 \\
\hline \multicolumn{5}{|l|}{ Reflectance of: } \\
\hline Gluteus superficialis, $a^{*}$ value & $\mathrm{a}^{*} \mathrm{GS}$ & 484 & 8.20 & 2.44 \\
\hline Biceps femoris, $a^{*}$ value & $\mathrm{a}{ }^{*} \mathrm{BF}$ & 484 & 7.63 & 2.37 \\
\hline Gluteus superficialis, $b^{*}$ value & $\mathrm{b}^{*} \mathrm{GS}$ & 484 & 7.20 & 2.42 \\
\hline Biceps femoris, $b^{*}$ value & $\mathrm{b}^{*} \mathrm{BF}$ & 484 & 6.39 & 2.30 \\
\hline Gluteus superficialis, $\mathrm{L}^{*}$ value & $\mathrm{L}^{*} \mathrm{GS}$ & 484 & 46.1 & 4.2 \\
\hline Biceps femoris, $\mathrm{L}^{*}$ value & $\mathrm{L}^{*} \mathrm{BF}$ & 484 & 47.0 & 4.0 \\
\hline \multicolumn{5}{|l|}{ Water-holding capacity, s } \\
\hline Gluteus superficialis & WHC_GS & 484 & 170.8 & 26.6 \\
\hline Biceps femoris & WHC_BF & 484 & 112.2 & 63.0 \\
\hline
\end{tabular}

at convergence and used to compute average values for each line $\times$ generation combination.

\section{RESULTS}

Significance of fixed effects, covariates, random effects, and total variation explained by fixed effects $\left(\mathrm{R}^{2}\right)$ are given in Table 3. A moderate proportion (24 to $29 \%$ ) of the total variation was explained by the fixed effect model for LGTH, ABT, and LMC. In contrast, the fixed effect model explained 30 to $50 \%$ of the total variation for DP and the weight of joints traits, except for LFWT. Inbreeding significantly decreased performance level for BFWT, BEWT, FWT, and LOWT. Body weight affected $(P<0.05)$ all traits except DP and LMC. Date of slaughter was the main fixed effect influencing meat quality characteristics: it explained from 36 to $50 \%$ of the total variation of ultimate $\mathrm{pH}$ and color measurements. Its effect was of less importance for muscle lightness and water-holding capacity, explaining 13 to $21 \%$ of the phenotypic variation for these traits.

Genetic parameter estimates for OR and PS were remarkably stable across the different 3 -trait analyses and were the same as those reported by Rosendo et al. (2007b). The REML estimates of heritability and common litter effects for carcass and meat quality traits are given in Table 4. Estimates had rather large SE due to the rather limited amount of data. With the exception of the small value obtained for DP (0.08) and the moderate estimates for SWT and HEWT $(0.28$ and 0.38 , respectively), carcass traits had high heritability values (from 0.48 to 0.72 ). Common litter effects were close to zero for some traits, but were far from negligible for other traits (up to 0.09). Estimates of heritability were moderate for $\mathrm{pH}$ measurements, for $\mathrm{a}^{*}$ and $\mathrm{b}^{*}$ color parameters and the lightness of GS traits (from 0.26 to 0.45 ). Conversely, very low $\mathrm{h}^{2}$ values were obtained for $\mathrm{L}^{*} \mathrm{BF}$ and the 2 water-holding capacity measurements. The magnitude of common litter effects was in the same range as that obtained for carcass traits $(0.00$ to 0.09$)$.

Estimates of phenotypic and genetic correlations between the selection criteria and carcass traits and meat quality traits are shown in Table 5. Phenotypic correlations between both OR or SP and carcass composition traits were all very weak $(-0.10$ to 0.06$)$. Genetic correlations between OR and carcass traits were also very low; only one value had an absolute value above $0.10(-0.17 \pm 0.14$ with LGTH). The situation was not much different for PS; only 4 estimates were outside the interval -0.10 to 0.10 . Though not significant, these values (i.e., -0.19 with $\mathrm{LMC} ;-0.13$ with $\mathrm{LOWT}$; 0.16 with $\mathrm{ABT}$ ) might indicate a small antagonism between PS and carcass leanness.

Similarly, phenotypic correlations with meat quality traits were all small (less than 0.10 in absolute values). 
Table 3. Models of analyses, significance, and total variation explained by fixed-effect terms $\left(\mathrm{R}^{2}\right)$

\begin{tabular}{|c|c|c|c|c|c|c|c|c|c|}
\hline \multirow[b]{2}{*}{ Trait $^{1}$} & \multirow[b]{2}{*}{$\mathrm{R}^{2}$} & \multicolumn{4}{|c|}{ Fixed effect } & \multicolumn{2}{|c|}{ Covariate } & \multicolumn{2}{|c|}{ Random effect ${ }^{2}$} \\
\hline & & Sex & Line & $\begin{array}{l}\text { Parity } \\
\text { of dam }\end{array}$ & $\begin{array}{l}\text { Contemporary } \\
\text { group }^{3}\end{array}$ & Inbreeding & $\begin{array}{l}\text { BW at } \\
\text { slaughter }\end{array}$ & Animal & Litter \\
\hline Dressing percentage & 0.33 & $* * *$ & ns & ns & $* * *$ & ns & ns & $\mathrm{X}$ & - \\
\hline Carcass length & 0.24 & $* * *$ & ns & * & ** & ns & $* * *$ & $\mathrm{X}$ & $\mathrm{X}$ \\
\hline Average backfat thickness & 0.27 & $* * *$ & ns & $* * *$ & $* * *$ & ns & $* * *$ & $\mathrm{X}$ & $\mathrm{X}$ \\
\hline Loin weight & 0.35 & $* * *$ & + & $*$ & $* * *$ & $*$ & $* * *$ & $\mathrm{X}$ & $\mathrm{X}$ \\
\hline Shoulder weight & 0.30 & $*$ & + & * & $* * *$ & ns & $* * *$ & $\mathrm{X}$ & $\mathrm{X}$ \\
\hline Feet weight & 0.41 & $* *$ & ns & ns & $* * *$ & $* *$ & $* * *$ & $\mathrm{X}$ & - \\
\hline Leaf fat weight & 0.19 & $* * *$ & ns & ns & $* *$ & ** & $* * *$ & $\mathrm{X}$ & - \\
\hline Belly weight & 0.33 & ns & ns & ns & $* * *$ & $* *$ & $* * *$ & $\mathrm{X}$ & - \\
\hline Head weight & 0.37 & ns & ns & ns & $* * *$ & ns & $* * *$ & $\mathrm{X}$ & - \\
\hline $\mathrm{a}^{*}$ value, GS muscle & 0.48 & ns & ns & ns & $* * *$ & ns & $*$ & $\mathrm{X}$ & - \\
\hline $\mathrm{a}^{*}$ value, $\mathrm{BF}$ muscle & 0.42 & $\mathrm{~ns}$ & ns & ns & $* * *$ & ns & $*$ & $\mathrm{X}$ & $\mathrm{X}$ \\
\hline $\mathrm{b}^{*}$ value, GS muscle & 0.57 & $\mathrm{~ns}$ & + & ns & $* * *$ & ns & $*$ & $\mathrm{X}$ & $\mathrm{X}$ \\
\hline $\mathrm{b}^{*}$ value, $\mathrm{BF}$ muscle & 0.55 & $\mathrm{~ns}$ & ns & ns & $* * *$ & ns & $\mathrm{ns}$ & $\mathrm{X}$ & $\mathrm{X}$ \\
\hline $\mathrm{L}^{*}$ value, GS muscle & 0.20 & ns & + & ns & $* *$ & ns & ns & $\mathrm{X}$ & $\mathrm{X}$ \\
\hline $\mathrm{L}^{*}$ value, $\mathrm{BF}$ muscle & 0.13 & $\mathrm{~ns}$ & ns & ns & $* *$ & ns & ns & $\mathrm{X}$ & $\mathrm{X}$ \\
\hline WHC, GS muscle & 0.18 & $\mathrm{~ns}$ & $*$ & ns & $* *$ & ns & $*$ & $\mathrm{X}$ & - \\
\hline WHC, BF muscle & 0.21 & $\mathrm{~ns}$ & ns & ns & $* *$ & $\mathrm{~ns}$ & $\mathrm{~ns}$ & $\mathrm{X}$ & - \\
\hline
\end{tabular}

${ }^{1} \mathrm{GS}, \mathrm{BF}$, and $\mathrm{AF}=$ gluteus superficialis, biceps femoris, and adductor femoris muscles, respectively. $\mathrm{pH} 24=\mathrm{pH}$ recorded $24 \mathrm{~h}$ after slaughter. $\mathrm{a}^{*}, \mathrm{~b}^{*}$, and $\mathrm{L}^{*}=$ reflectance measurements: redness/greenness, yellowness/blueness, and lightness, respectively. WHC $=$ water-holding capacity.

${ }^{2}$ Random effect considered (X) or not considered (-) in the model.

${ }^{3}$ Contemporary group $=$ batch effect for carcass traits and slaughter date effect for meat quality traits.

*** $P<0.001 ;{ }^{* *} P<0.01 ;{ }^{*} P<0.05 ;+P<0.10 ;$ ns $=$ not significant.

With a single exception, genetic correlations of OR and PS with $\mathrm{pH}$ measurements were nonsignificant $(P>$ $0.05)$, but consistently positive $(0.25$ to 0.37$)$. Consistently positive genetic correlations were also obtained between PS and $a^{*}$ and $b^{*}$ measurements, whereas positive and negative values were obtained with OR. Conversely, genetic correlations of muscle lightness and water-holding capacity with OR and PS were all negative.

First analyses of line differences on generations 5 to 7 did not show any significant $(P>0.10)$ line $\times$ generation interaction or generation effect. Average line effects and differences over the 3 generations were hence computed. Estimates for LC and mixed model of contrasts between these overall line effects are shown in Table 6 . They were consistent in sign and magnitude. Line differences were not significant $(P>0.10)$ for the vast majority of the traits analyzed. The only exceptions for carcass traits were loin weight, which tended to increase in the PS line $(P<0.10)$, and SWT, which tended to increase in the OR line $(P<0.10)$. No difference $(P>0.10)$ was observed for meat quality traits in the OR line. Conversely, $\mathrm{pH}$ values tended to increase in the PS, with significant differences $(P<0.05)$ for 2 of the $4 \mathrm{pH}$ measurements. There were also tendencies toward a greater $b^{*}$ value and a reduced water-holding capacity on GS muscle.

\section{DISCUSSION}

For most composition carcass traits, the heritability values found are in agreement with the average literature values reported by Sellier (1998) and with the estimates obtained by Larzul et al. (1999b) using data that were partly common (CON line) to the current data. Heritability of DP $(0.08 \pm 0.04)$ is close to previous estimates $(0.11 \pm 0.04)$ of Larzul et al. (1999b), but is noticeably less than the estimates reported by Ducos et al. (1993) and Tribout et al. (1996) and the average literature value of 0.30 reported by Ducos (1994). As suggested by Larzul et al. (1999b), the low heritability estimate might be due to the fact that slaughter BW was recorded before feed withdrawal in the present study, whereas it was recorded on fasted animals in most other studies. Conversely, the heritability value obtained for ABT is greater than most estimates reported in the literature (Lo et al., 1992; Bidanel et al., 1994b; Serenius et al., 2004) and close to the estimates reported by Larzul et al. (1997).

In this study, the ultimate $\mathrm{pH}$ traits had high heritability values. Estimates were 0.35 on average, superior to the average literature value of 0.21 reported in Sellier (1998). They were also greater than the estimates reported by Larzul et al. (1999a) and van Wijk et al. (2005), but were close to the value reported by Nguyen 
Table 4. Estimates of heritability $( \pm \mathrm{SE})$ and common litter effect for carcass and meat quality traits

\begin{tabular}{|c|c|c|c|}
\hline Trait $^{1}$ & Heritability \pm SE & $\begin{array}{c}\text { Common } \\
\text { litter effect }{ }^{2}\end{array}$ & $\begin{array}{c}\text { Phenotypic } \\
\text { variance }\end{array}$ \\
\hline Dressing percentage, $\%$ & $0.08 \pm 0.04$ & - & 6.8 \\
\hline Carcass length, mm & $0.58 \pm 0.10$ & 0.09 & 747 \\
\hline Average backfat thickness, mm & $0.70 \pm 0.10$ & 0.04 & 19.9 \\
\hline Backfat weight, $\mathrm{kg}$ & $0.68 \pm 0.08$ & 0.04 & 0.45 \\
\hline Ham weight, $\mathrm{kg}$ & $0.48 \pm 0.11$ & 0.08 & 0.24 \\
\hline Loin weight, $\mathrm{kg}$ & $0.55 \pm 0.09$ & 0.07 & 0.56 \\
\hline Shoulder weight, $\mathrm{kg}$ & $0.28 \pm 0.06$ & 0.03 & 0.12 \\
\hline Feet weight, $\mathrm{kg}$ & $0.66 \pm 0.09$ & - & 0.01 \\
\hline Leaf fat weight, $\mathrm{kg}$ & $0.72 \pm 0.08$ & - & 0.03 \\
\hline Belly weight, $\mathrm{kg}$ & $0.69 \pm 0.10$ & - & 0.23 \\
\hline Head weight, $\mathrm{kg}$ & $0.38 \pm 0.08$ & - & 0.74 \\
\hline Estimated lean meat content, $\%$ & $0.74 \pm 0.10$ & 0.04 & 8.9 \\
\hline pH24 of LM muscle & $0.35 \pm 0.12$ & 0.08 & 0.05 \\
\hline pH24 of GS muscle & $0.34 \pm 0.13$ & 0.07 & 0.05 \\
\hline $\mathrm{pH} 24$ of $\mathrm{BF}$ muscle & $0.29 \pm 0.11$ & 0.07 & 0.06 \\
\hline pH24 of AF muscle & $0.45 \pm 0.12$ & 0.08 & 0.11 \\
\hline $\mathrm{a}^{*}$ value, GS muscle & $0.34 \pm 0.12$ & - & 3.78 \\
\hline $\mathrm{a}^{*}$ value, $\mathrm{BF}$ muscle & $0.45 \pm 0.13$ & 0.09 & 4.26 \\
\hline $\mathrm{b}^{*}$ value, GS muscle & $0.28 \pm 0.11$ & 0.02 & 3.05 \\
\hline $\mathrm{b}^{*}$ value, $\mathrm{BF}$ muscle & $0.26 \pm 0.11$ & 0.02 & 3.28 \\
\hline $\mathrm{L}^{*}$ value, GS muscle & $0.30 \pm 0.11$ & 0.04 & 16.4 \\
\hline $\mathrm{L}^{*}$ value, $\mathrm{BF}$ muscle & $0.13 \pm 0.11$ & 0.09 & 15.3 \\
\hline WHC, GS muscle, s & $0.11 \pm 0.06$ & - & 645 \\
\hline WHC, BF muscle, s & $0.03 \pm 0.06$ & - & 651 \\
\hline
\end{tabular}

${ }^{1} \mathrm{GS}, \mathrm{BF}$, and $\mathrm{AF}=$ gluteus superficialis, biceps femoris, and adductor femoris muscles, respectively. $\mathrm{pH} 24=$ $\mathrm{pH}$ recorded $24 \mathrm{~h}$ after slaughter. $\mathrm{a}^{*}, \mathrm{~b}^{*}$, and $\mathrm{L}^{*}=$ reflectance measurements: redness/greenness, yellowness/ blueness, and lightness, respectively. WHC $=$ water-holding capacity.

${ }^{2}$ The dash $(-)$ indicates that the common litter effect was nonsignificant and was removed from final analyses.

Table 5. Estimates of phenotypic and genetic correlations $( \pm \mathrm{SE})$ between the selection criteria and carcass composition and meat quality traits

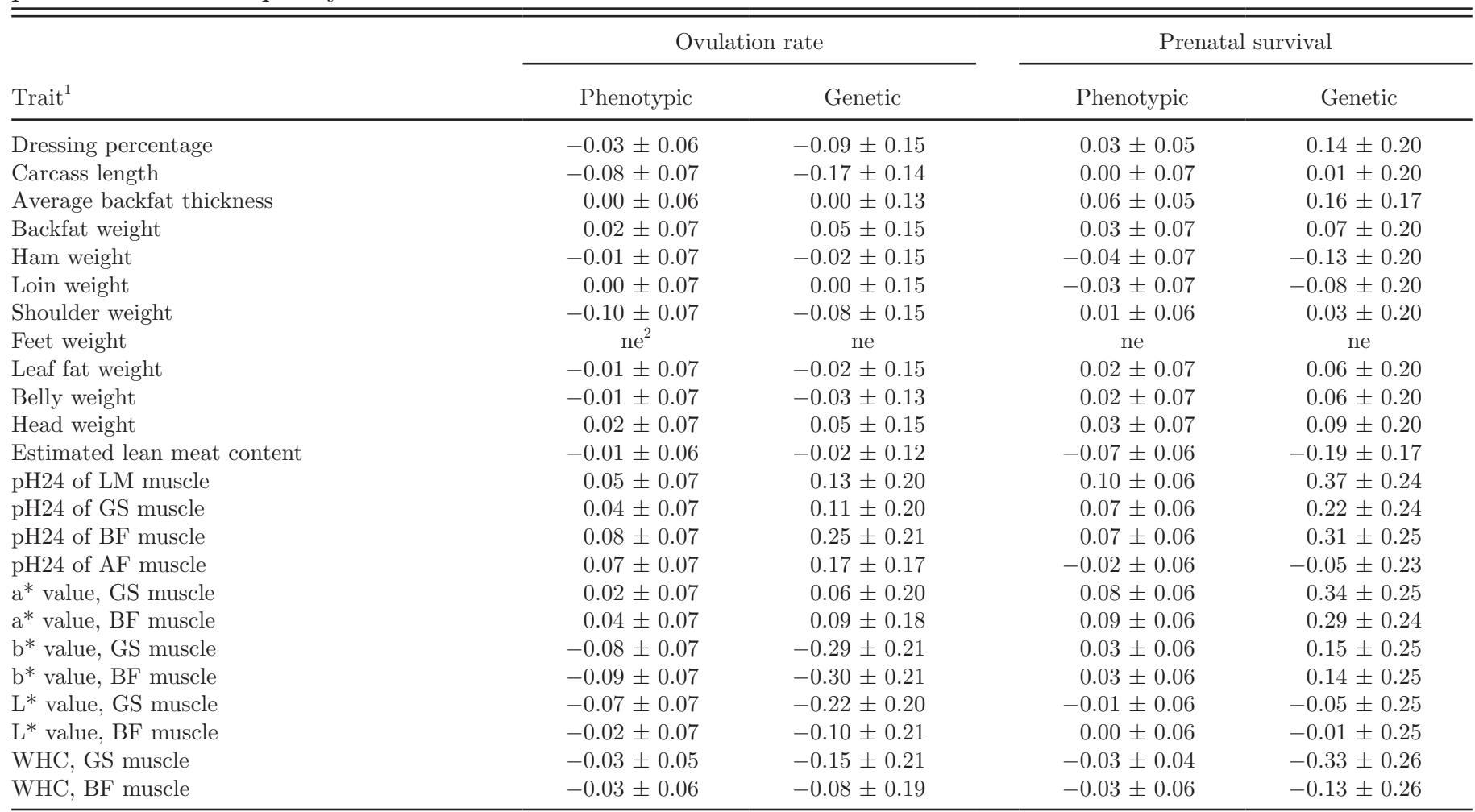

${ }^{1} \mathrm{GS}, \mathrm{BF}$, and $\mathrm{AF}=$ gluteus superficialis, biceps femoris, and adductor femoris muscles, respectively. $\mathrm{pH} 24=\mathrm{pH}$ recorded $24 \mathrm{~h}$ after slaughter. $\mathrm{a}^{*}, \mathrm{~b}^{*}$, and $\mathrm{L}^{*}=$ reflectance measurements: redness/greenness, yellowness/blueness, and lightness, respectively. WHC = water-holding capacity.

${ }^{2}$ ne $=$ not estimated because of convergence problems. 
Table 6. Least squares (LS) and mixed model (MM) estimates ( \pm SE) of line differences for carcass and meat quality traits after 6 generations of selection

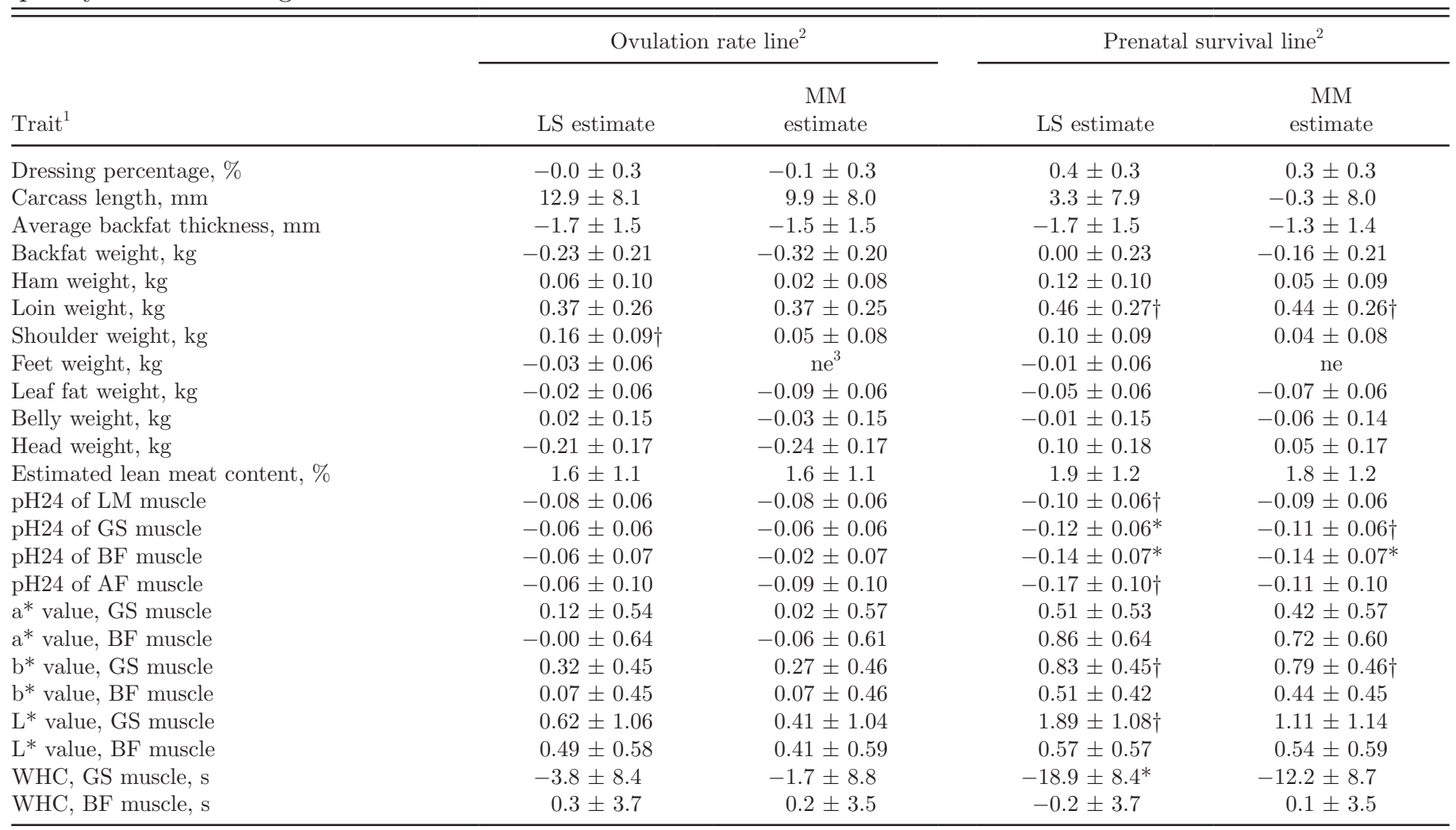

${ }^{1} \mathrm{GS}, \mathrm{BF}$, and $\mathrm{AF}=$ gluteus superficialis, biceps femoris, and adductor femoris muscles, respectively. $\mathrm{pH} 24=\mathrm{pH}$ recorded $24 \mathrm{~h}$ after slaughter. $\mathrm{a}^{*}, \mathrm{~b}^{*}$, and $\mathrm{L}^{*}=$ reflectance measurements: redness/greenness, yellowness/blueness, and lightness, respectively. WHC $=$ water-holding capacity.

${ }^{2}$ Difference between selected and control lines; $\dagger P<0.10 ; * P<0.05$.

${ }^{3}$ ne $=$ not estimated because of convergence problems.

et al. (2006). The heritability estimates for reflectance are within the range found in the literature (Lo et al., 1992; de Vries et al., 1994; Knapp et al., 1997; Sellier, 1998). Among meat quality traits, heritability values for WHC_GS and WHC_BF were in agreement with those reported by Tribout et al. (1996) and Sonesson et al. (1998), but less than the estimates presented by the most recent literature reviews (Larzul et al., 1999a; Hermesch et al., 2000a). With estimates ranging from 2 to $9 \%$ of the phenotypic variance, common litter effects fell in the range of values reported in the literature.

Overall, genetic correlations between $\mathrm{OR}$ or SP and carcass composition traits were not significantly different from zero. Yet, correlation estimates with fatness/ leanness traits tended to show a small antagonism between carcass leanness and OR or SP. Literature estimates of the genetic correlation between ABT and OR are close to zero (Rothschild and Bidanel, 1998; Ruiz-Flores and Johnson, 2001). An absence of genetic association between production and reproduction traits has been reported in numerous studies (e.g., Noguera et al., 2002; Serenius et al., 2004; Arango et al., 2005). Yet other recent studies have found a small unfavorable genetic correlation between carcass composition and litter size (e.g., Hermesch et al., 2000b; Zhang et al., 2000; Chen et al., 2003; Holm et al., 2004; Tribout and Bidanel, 2008). This unfavorable relationship may result from the detrimental effects on placental development of increased uterine crowding during early gestation, which is a critical period for the muscle development of embryos (Foxcroft et al., 2006). Embryos are then more likely to suffer from intrauterine growth retardation and have reduced numbers of muscle fibers and result in pigs with reduced growth performance and lean content at slaughter (Foxcroft et al., 2006; Rehfeldt and Kuhn, 2006). It may also be because leaner sows would have more difficulties mobilizing their body reserves to support the needs of embryos/piglets during gestation and lactation, as well as because of an unfavorable effect of a nutritional unbalance in late lactation on the subsequent ovulation or implantation rates.

Estimates of genetic correlations between OR and the different ultimate $\mathrm{pH}$ traits varied from 0.11 to 0.25 and from -0.05 to 0.37 between $\mathrm{SP}$ and ultimate $\mathrm{pH}$ traits, but also had very large SE (from 0.17 to 0.21 and 0.23 to 0.25 , respectively), making it difficult to draw a conclusion regarding the genetic relationships between $\mathrm{OR}$ and meat quality. No other estimate of genetic correlations between OR or PS and meat quality traits is, to our knowledge, available in the literature to compare with results reported herein. More generally, few estimates of genetic relationships between reproduction and meat quality traits are available in the literature. Hermesch et al. (2000b) reported a negative genetic 
correlation $(-0.26)$ between ultimate $\mathrm{pH}$ and number of piglets born alive, indicating that an increased litter size is associated with a smaller ultimate $\mathrm{pH}$. Genetic correlations between reflectance, lightness, water-holding capacity, and OR or PS traits were inconsistent and mostly of small magnitude, indicating no clear genetic relationships between these traits. However, genetic correlation between OR or PS and water-holding capacity traits were weak and negative. In contrast, Hermesch et al. (2000b) presented slightly positive genetic correlations between water-holding capacity and number of piglets born alive in first and second parity, but this correlation was not confirmed for the number of piglets born alive in third parity litters.

Line differences in the last generations of the experiment indicate that correlated responses to selection on carcass traits are limited. It has to be noted that the tendency toward an increase in loin weight in the PS line is not consistent with the weakly unfavorable genetic correlations between PS and carcass leanness traits. No clear explanation for this discrepancy was found. Conversely, the tendency toward an increase in ultimate $\mathrm{pH}$ is consistent with genetic parameter estimates. Larzul et al. (1999b) estimated correlated responses to selection for a reduced muscle glycolytic potential, which is strongly correlated with ultimate $\mathrm{pH}$, in a Large White population issued from the same base population and obtained little correlated response for litter traits.

In conclusion, this study provides first estimates of genetic correlations of components of litter size (i.e., OR and PS) with carcass and meat quality traits. They globally confirm that both groups of traits are weakly correlated, although there might be a small antagonism between OR or PS and carcass leanness and a weak positive (i.e., favorable) relationship with meat ultimate $\mathrm{pH}$.

\section{LITERATURE CITED}

Arango, J., I. Misztal, S. Tsuruta, M. Culbertson, and W. Herring. 2005. Threshold-linear estimation of genetic parameters for farrowing mortality, litter size, and test performance of Large White sows. J. Anim. Sci. 83:499-506.

Bidanel, J. P., A. Ducos, R. Guébles, and F. Labroue. 1994b. Genetic parameters of backfat thickness, age at $100 \mathrm{~kg}$ and ultimate $\mathrm{pH}$ in on-farm tested French Landrace and Large White pigs. Livest. Prod. Sci. 40:291-301.

Bidanel, J. P., J. Gruand, and C. Legault. 1994a. An overview of twenty years of selection for litter size in pigs using 'Hyperprolific' schemes. Pages 512-515 in Proc. 5th World Congr. Genet. Appl. Livest. Prod. Vol. 17. C. Smith, J. S. Gavora, B. Benkel, J. Chesnais, W. Fairfull, J. P. Gibson, B. W. Kennedy, and E. B. Burnside, ed. Univ. Guelph, Guelph, Ontario, Canada.

Blasco, A., J. P. Bidanel, and D. Sorensen. 1998. A Bayesian analysis of genetic parameters and selection response for litter size components in pigs. Genetics 149:301-306.

Charpentier, J., G. Monin, and L. Ollivier. 1971. Correlations between carcass characteristics and meat quality in Large White pigs. Pages 255-260 in Proc. 2nd Int. Symp. on condition and meat quality of pigs, Zeist, the Netherlands. Pudoc, Wageningen, the Netherlands.
Chen, P., T. J. Baas, J. W. Mabry, and K. J. Koehler. 2003. Genetic correlations between lean growth and litter traits in U.S. Yorkshire, Duroc, Hampshire, and Landrace pigs. J. Anim. Sci. 81:1700-1705.

De Vries, A. G., P. G. van der Wal, T. Long, G. Eikelenboom, and J. W. Merks. 1994. Genetic parameters of pork quality and production traits in Yorkshire populations. Livest. Prod. Sci. 40:277-289.

Ducos, A. 1994. Paramètres génétiques des caractères de production chez le porc. Mise au point bibliographique . Techni-porc $17: 35-67$.

Ducos, A., J. P. Bidanel, V. Ducrocq, D. Biochard, and E. Groeneveld. 1993. Multivariate restricted maximum likelihood estimation of genetic parameters for growth, carcass and meat quality traits in French Large White pigs. Genet. Sel. Evol. 25:475-493.

Estany, J., D. Villalba, M. Tor, D. Cubiló, and J. L. Noguera. 2002. Correlated response to selection for litter size in pigs: II. Carcass, meat, and fat quality traits. J. Anim. Sci. 80:2566-2573.

Foxcroft, G. R., W. T. Dixon, S. Novak, C. T. Putman, S. C. Town, and M. D. A. Vinsky. 2006. The biological basis for prenatal programming of postnatal performance in pigs. J. Anim. Sci. 84:E105-E112.

Gilmour, A. R., B. J. Gogel, B. R. Cullis, S. J. Welham, and R. Thompson. 2002. ASReml User Guide Release 1.0. VSN Int. Ltd., Hemel Hempstead, UK.

Hamann, H., R. Steinheuer, and O. Distl. 2004. Estimation of genetic parameters for litter size as a sow and boar trait in German herdbook Landrace and Pietrain swine. Livest. Prod. Sci. 85:201-207.

Hermesch, S., B. G. Luxford, and H.-U. Graser. 2000a. Genetic parameters for lean meat yield, meat quality, reproduction and feed efficiency traits for Australian pigs. 1. Description of traits and heritability estimates. Livest. Prod. Sci. 65:239-248.

Hermesch, S., B. G. Luxford, and H.-U. Graser. 2000b. Genetic parameters for lean meat yield, meat quality, reproduction and feed efficiency traits for Australian pigs. 3. Genetic parameters for reproduction traits and genetic correlation with production, carcass and meat quality traits. Livest. Prod. Sci. 65:261270.

Holl, J. W., and O. W. Robinson. 2003. Result from nine generations of selection for increased litter size in swine. J. Anim. Sci. 81:624-629.

Holm, B., M. Baskken, G. Klemetssdal, and O. Vangen. 2004. Genetic correlations between reproduction and production traits in swine. J. Anim. Sci. 82:3458-3464.

Johnson, R. K., D. R. Zimmerman, and R. J. Kittok. 1984. Selection for components of reproduction in swine. Livest. Prod. Sci. 11:541-558.

Knapp, P., A. William, and J. Sölkner. 1997. Genetic parameters for lean meat content and meat quality traits in different pigs breeds. Livest. Prod. Sci. 52:69-73.

Larzul, C., L. Lefaucheur, P. Ecolan, J. Gogué, A. Talmant, P. Sellier, P. Le Roy, and G. Monin. 1997. Phenotypic and genetic parameters for longissimus muscle fiber characteristics in relation to growth, carcass, and meat quality traits in Large White pigs. J. Anim. Sci. 75:3126-3137.

Larzul, C., P. Le Roy, J. Gogué, J. Gogué, A. Talmant, B. Jacquet, L. Lefaucheur, P. Ecolan, P. Sellier, and G. Monin. 1999a. Selection for reduced muscle glycolytic potential in Large White pigs. II. Correlated responses in meat quality and muscle compositional traits. Genet. Sel. Evol. 31:61-76.

Larzul, C., P. Le Roy, J. Gogué, A. Talmant, G. Monin, and P. Sellier. 1999b. Selection for reduced muscle glycolytic potential in Large White pigs. III. Correlated responses in growth rate, carcass composition and reproductive traits. Genet. Sel. Evol. $31: 149-161$

Lo, L. L., D. G. McLaren, F. K. McKeith, R. L. Fernando, and J. Novakofski. 1992. Genetic analyses of growth, real-time ultrasound, carcass, and pork quality traits in Duroc and Lan- 
drace Pigs: II. Heritabilities and correlations. J. Anim. Sci. 70:2387-2396.

Neumaier, A., and E. Groeneveld. 1998. Restricted maximum likelihood estimation of covariances in sparse linear models. Genet. Sel. Evol. 30:3-26.

Nguyen, N. H., C. P. McPhee, and G. R. Trout. 2006. Responses in carcass lean $\mathrm{pH}$ at 24 hours post-mortem in lines of Large White pigs selected for growth rate on a fixed ration over a set time. Livest. Prod. Sci. 100:84-90.

Noguera, J. L., L. Varona, D. Babot, and J. Estany. 2002. Multivariate analysis of litter size for multiple parities with production traits in pigs: II. Response to selection for litter size and correlated response to production traits. J. Anim. Sci. 80:2548-2555.

Patterson, H. D., and R. Thompson. 1971. Recovery of inter-block information when block sizes are unequal. Biometrika 58:545554 .

Rehfeldt, C., and G. Kuhn. 2006. Consequences of birth weight for postnatal growth performance and carcass quality in pigs as related to myogenesis. J. Anim. Sci. 84:E113-E123.

Rosendo, A., L. Canario, T. Druet, J. Gogué, and J. P. Bidanel. 2007a. Correlative responses for pre- and postweaning growth and backfat thickness to six generations of selection for ovulation rate or prenatal survival in French Large White pigs. J. Anim. Sci. 85:3209-3217.

Rosendo, A., T. Druet, J. Gogué, and J. P. Bidanel. 2007b. Direct responses to six generations of selection for ovulation rate or prenatal survival in Large White pigs. J. Anim. Sci. 85:346364.

Rosendo, A., T. Druet, J. Gogué, L. Canario, and J. P. Bidanel. 2007c. Correlative responses for litter traits to six generations of selection for ovulation rate or prenatal survival in French Large White pigs. J. Anim. Sci. 85:1615-1624.

Rothschild, M. F., and J. P. Bidanel. 1998. Biology and Genetics of Reproduction. Pages 313-344 in The Genetics of the Pig. M. F. Rothschild and A. Ruvinsky, ed. CAB Int., Wallingford, UK.

Ruiz-Flores, A., and R. K. Johnson. 2001. Direct and correlated responses to two-stage selection for ovulation rate and number of fully formed pigs at birth in swine. J. Anim. Sci. 79:22862299 .
Sellier, P. 1998. Genetics of meat and carcass traits. Pages 463-510 in The Genetics of the Pig. M. F. Rothschild and A. Ruvinsky, ed. CAB Int., Wallingford, UK.

Serenius, T., M.-L. Sevon-Aimónen, A. Kause, E. A. Mäntysaari, and A. Mäki-Tanila. 2004. Genetic associations of prolificacy with performance, carcass, meat quality, and leg conformation traits in the Finnish Landrace and Large White pig populations. J. Anim. Sci. 82:2301-2306.

Sonesson, A. K., K. H. de Greef, and T. H. E. Meuwissen. 1998. Genetic parameters and trends of meat quality, carcass composition and performance traits in two selected lines of large white pigs. Livest. Prod. Sci. 57:23-32.

Tribout, T., and J. P. Bidanel. 2008. Paramètres génétiques du nombre de porcelets nés vivants par portée et relations avec les caractères du contrôle en ferme dans les populations porcines Large White type femelle et Landrace Français. Pages 113-118 in 40èmes Journées de la Recherche Porcine, Paris, France. IFIP, Institute du Porc, Paris, France.

Tribout, T., J. C. Caritez, J. Gogué, J. Gruand, Y. Billon, M. Bouffaud, H. Lagant, J. Le Dividich, F. Tomas, H. Quesnel, R. Guéblez, and J. P. Bidanel. 2003. Estimation, par utilisation de semence congelée, du progrès génétique réalisé en France entre 1977 et 1998 dans la race porcine Large White: Résultats pour quelques caractères de reproduction femelle. Pages 285-292 in 35 èmes Journées de la Recherche Porcine, Paris, France. IFIP, Institute du Porc, Paris, France.

Tribout, T., H. Garreau, and J. P. Bidanel. 1996. Paramètres génétiques de quelques caractères de qualité de la viande dans les races porcines Large White et Landrace Français. Pages 31-38 in 28ème Journées de la Recherche Porcine, Paris, France. IFIP, Institute du Porc, Paris, France.

van Wijk, H. J., D. J. G. Arts, J. O. Matthews, M. Webster, B. J. Ducro, and E. F. Knol. 2005. Genetic parameters for carcass composition and pork quality estimated in a commercial production chain. J. Anim. Sci. 83:324-333.

Zhang, S., J. P. Bidanel, T. Burlot, C. Legault, and J. Naveau. 2000. Genetic parameters and genetic trends in the Chinese x European Tiameslan composite line. I. Genetic parameters. Genet. Sel. Evol. 32:41-56. 
References

This article cites 33 articles, 17 of which you can access for free at: http://www.journalofanimalscience.org/content/88/3/903\#BIBL 